\title{
Some histological changes in chronic bronchitis and asthma
}

\author{
G. S A L V A T O \\ From the City Hospital, Merano, Italy
}

\begin{abstract}
The differences in two groups of patients (24 with chronic bronchitis and 24 with bronchial asthma) were compared by bronchoscopy and bronchial biopsies. The same investigations were carried out on 24 healthy control subjects. The only bronchoscopic difference between the two groups was hypertonicity of the bronchial wall, which was frequent in the asthmatics and absent in the chronic bronchitics. Mucus was scanty and viscous in the asthmatics and more abundant and watery in the chronic bronchitics. Hypersecretion of mucus occurred in both groups. In asthma the mucous hyperplasia affected chiefly the goblet cells. In chronic bronchitis the deeper bronchial glands were affected as .well as the goblet cells. In asthma the mucus stained predominantly with the periodic-acid Schiff technique, and was thus presumed to contain much neutral mucopolysaccharide. In chronic bronchitis the mucus was strongly alcian blue positive and was thought to consist largely of acid mucopolysaccharide. Thickening of the basement membrane was almost constant in bronchial asthma and rare in chronic bronchitis. Tissue eosinophilia was very frequent and intense in asthma but infrequent and sparse in chronic bronchitis. Mast cells were degranulated and decreased in number in asthma but increased in number and packed with granules in chronic bronchitis. It is presumed that there is a relation between tissue eosinophilia and degranulation of mast cells. The study confirms that bronchial asthma and chronic bronchitis are two distinct diseases, both with a separate pathology.
\end{abstract}

I have studied biopsy material taken during bronchoscopy on three groups of subjects-24 suffering from chronic bronchitis, 24 affected with bronchial asthma, and 24 healthy controls.

The patients with chronic bronchitis had a productive cough which had persisted for at least three months a year for the last two years, and had an excessive production of bronchial mucus which could not be attributed to any other specific or localized pulmonary disease. Seven of these patients had cor pulmonale (Table I).

The patients with bronchial asthma had a history of paroxysmal attacks of dyspnoea and wheezing (especially at night) which varied rapidly over a period of time and which disappeared spontaneously or with bronchodilator or corticosteroid therapy (Table II).

The normal subjects were patients without symptoms of chronic bronchitis or asthma, in whom bronchoscopy showed a normal mucosa.

METHOD

Bronchoscopy was carried out under local anaes- thesia with $2 \%$ Xylocaine and the histological changes were analysed on biopsies taken from the carina of the middle lobe bronchus. Bronchoscopy was performed on the asthmatics during the attack or after 24 to 48 hours. Most patients did not receive corticosteroids before bronchoscopy to avoid alterations by these drugs of the bronchial tissues, especially of the mast cells (Salvato, 1959) and eosinophils (Cardell, 1963).

Some patients were treated at home with steroids before coming to hospital, and in such cases the bronchoscopy was undertaken at least 15 days after the cortisone had been stopped. In the $N$ bronchitics the examination was carried out while the patients were under treatment with antibiotics.

The shape of the tracheal and bronchial walls and their alterations during breathing were analysed ; macroscopical signs of tracheobronchial inflammation were sought such as:

(a) thickening of the mucosa, which could be evaluated from the decreased visibility of the tracheobronchial cartilages and from the thickness of the bronchial carinas;

(b) redness of the mucosa ; 
T A B L E I

CHRONIC BRONCHITIS GROUP

\begin{tabular}{|c|c|c|c|c|c|c|c|}
\hline \multirow{2}{*}{$\begin{array}{l}\text { Case } \\
\text { No. }\end{array}$} & \multirow{2}{*}{$\begin{array}{l}\text { Sex/ } \\
\text { Age }\end{array}$} & \multirow{2}{*}{ Grade } & \multirow{2}{*}{$\begin{array}{c}\text { Cor } \\
\text { Pul- } \\
\text { monale }\end{array}$} & \multicolumn{2}{|c|}{$\begin{array}{l}\text { Eosinophils } \\
\text { in }\end{array}$} & \multirow{2}{*}{$\begin{array}{l}\text { Eosino- } \\
\text { phils in } \\
\text { Sub- } \\
\text { epithelial } \\
\text { Connec- } \\
\text { tive Tissue } \\
(\%)\end{array}$} & \multirow{2}{*}{$\begin{array}{c}\text { Mast } \\
\text { Cells }^{2} \text { in } \\
\text { Sub- } \\
\text { epithelial } \\
\text { Connec- } \\
\text { tive Tissue } \\
\text { (over 30 } \\
\text { micro- } \\
\text { scopical } \\
\text { fields) }\end{array}$} \\
\hline & & & & Blood $^{1}$ & Sputum & & \\
\hline $\begin{array}{r}1 \\
2 \\
3 \\
4 \\
5 \\
6 \\
7 \\
8 \\
9 \\
10 \\
11 \\
12 \\
13 \\
14 \\
15 \\
16 \\
17 \\
18 \\
19 \\
20 \\
21 \\
22 \\
23 \\
24\end{array}$ & $\begin{array}{ll}\text { M } & 60 \\
\text { F } & 51 \\
\text { M } & 61 \\
\text { M } & 44 \\
\text { M } & 56 \\
\text { M } & 38 \\
\text { F } & 66 \\
\text { M } & 58 \\
\text { M } & 68 \\
\text { M } & 46 \\
\text { M } & 66 \\
\text { M } 56 \\
\text { M } 59 \\
\text { M } & 72 \\
\text { M } & 54 \\
\text { M } & 56 \\
\text { F } & 60 \\
\text { M } 54 \\
\text { M } & 46 \\
\text { F } & 67 \\
\text { M } & 57\end{array}$ & $\begin{array}{l}2 \\
2 \\
1 \\
2 \\
2 \\
1 \\
1 \\
2 \\
1 \\
1 \\
2 \\
1 \\
2 \\
1 \\
1 \\
2 \\
2 \\
2 \\
2 \\
2 \\
2 \\
2 \\
2 \\
2\end{array}$ & $\begin{array}{l}0 \\
0 \\
0 \\
+ \\
+ \\
0 \\
0 \\
0 \\
0 \\
0 \\
0 \\
0 \\
+ \\
0 \\
+ \\
0 \\
0 \\
0 \\
0 \\
0 \\
+ \\
0 \\
+ \\
+\end{array}$ & $\begin{array}{l}4 \\
0 \\
0 \\
2 \\
3 \\
0 \\
0 \\
0 \\
0 \\
0 \\
0 \\
0 \\
0 \\
1 \\
5 \\
0 \\
3 \\
2 \\
0 \\
4 \\
0 \\
0 \\
0 \\
0\end{array}$ & $\begin{array}{l}0 \\
0 \\
0 \\
0 \\
0 \\
0 \\
+ \\
0 \\
0 \\
0 \\
0 \\
0 \\
0 \\
0 \\
0 \\
0 \\
0 \\
0 \\
0 \\
0 \\
0 \\
0 \\
0 \\
+\end{array}$ & $\begin{array}{l}0 \cdot 50 \\
1.25 \\
0 \cdot 25 \\
0 \\
0 \\
0 \\
0 \\
0 \\
0 \\
0 \\
0 \\
0 \cdot 25 \\
0 \\
1 \cdot 25 \\
0 \\
0 \cdot 75 \\
0 \\
0 \cdot 50 \\
1 \cdot 25 \\
0 \cdot 50 \\
0 \cdot 50 \\
2 \\
0 \cdot 25 \\
2.75\end{array}$ & $\begin{array}{c}75 \cdot 3 \\
59 \cdot 2 \\
89 \\
61 \cdot 3 \\
75 \cdot 3 \\
53 \cdot 4 \\
121 \\
82 \cdot 2 \\
111 \cdot 3 \\
86 \cdot 4 \\
71 \cdot 3 \\
62 \cdot 1 \\
69 \cdot 1 \\
17 \cdot 3 \\
65 \cdot 1 \\
129 \cdot 4 \\
61 \cdot 4 \\
35 \cdot 3 \\
88 \cdot 2 \\
75 \\
74 \cdot 2 \\
69 \cdot 2 \\
102 \cdot 4 \\
72\end{array}$ \\
\hline
\end{tabular}

${ }^{1}$ Leucocytes: number within normal limits.

${ }^{2}$ Average of five enumerations.

(c) increased bronchial secretion ;

(d) alterations in sensitivity to cough reflex assessed by the presence or absence of cough after introduction of the bronchoscope into a main bronchus which might need to be sprayed with $2 \%$ Xylocaine.

The bronchial biopsy specimens were fixed in $10 \%$ formalin. After paraffin embedding the sections (thickness $5 \mu$ ) were stained with haematoxylin and eosin, $0.1 \%$ toluidine blue at $p \mathrm{H} 6.5$, and McManus-alcian blue and by the periodicacid Schiff (PAS) technique. A histological study was made of the following:

(1) the presence of hyperplasia of goblet cells and mucous glands ;

(2) the tinctorial properties of the mucus at these two sites and lying free on the epithelial surface ;

(3) the thickness of the epithelial basement membrane ; and

(4) the nature of the cellular exudate in the biopsy specimen. A differential count was made of the various cell types seen ; these included eosinophils, mast cells, lymphocytes, plasma cells, neutrophil polymorphs, and histiocytes. In each case 400 such cells were counted in a random field and the percentage of eosinophils present was recorded.
The number of mast cells present per 'microscopic area' of 30 fields was estimated in the following way. Mast cells were counted in 30 fields (ocular $\times 10$, objective $\times 100$ ) by choosing at random five fields on each of six sections. This procedure was repeated five times; hence 150 fields in 30 sections were examined in each patient. Since mast cells may be rich or poor in metachromatic granules, the two forms were counted separately, and for this differential count the degree of granulation was assessed by a method similar to that used by Shelley and Juhlin (1962) for blood basophils.

\section{HISTOLOGICAL FINDINGS}

\section{SURFACE EPITHELIUM}

Normal subjects The epithelium consisted of ciliated cells, irregularly scattered goblet cells, and intermediate cells resting on a basal cell layer. The goblet cells were fewer in number than the ciliated cells and in places they were grouped together. The mucus in some goblet cells stained positively with PAS but in others it stained with

T A B L E I I

BRONCHIAL ASTHMA GROUP

\begin{tabular}{|c|c|c|c|c|c|c|c|}
\hline \multirow{2}{*}{$\begin{array}{l}\text { Case } \\
\text { No. }\end{array}$} & \multirow{2}{*}{$\begin{array}{l}\text { Sex/ } \\
\text { Age }\end{array}$} & \multirow{2}{*}{$\begin{array}{l}\text { His- } \\
\text { tory } \\
\text { (yrs) }\end{array}$} & \multirow{2}{*}{ Allergy } & \multicolumn{2}{|c|}{$\begin{array}{l}\text { Eosinophils } \\
\text { in }\end{array}$} & \multirow{2}{*}{$\begin{array}{c}\text { Eosino- } \\
\text { phils in } \\
\text { Sub- } \\
\text { epithelial } \\
\text { Connec- } \\
\text { tive Tissue } \\
(\%)\end{array}$} & \multirow{2}{*}{$\begin{array}{c}\text { Mast } \\
\text { Cells }{ }^{2} \text { in } \\
\text { Sub- } \\
\text { epithelial } \\
\text { Connec- } \\
\text { tive Tissue } \\
\text { (over 30 } \\
\text { micro- } \\
\text { scopical } \\
\text { fields) }\end{array}$} \\
\hline & & & & $\begin{array}{c}\text { Blood }^{1} \\
(\%)\end{array}$ & Sputum & & \\
\hline $\begin{array}{l}25 \\
26 \\
27 \\
28 \\
29 \\
30 \\
31 \\
32 \\
33 \\
34\end{array}$ & $\begin{array}{ll}\text { F } & 32 \\
\text { M } & 68 \\
\text { M } & 20 \\
\text { M } & 52 \\
\text { F } & 49 \\
M & 46 \\
\text { M } & 46 \\
F & 44 \\
F & 21 \\
\text { M } & 49\end{array}$ & $\begin{array}{r}6 \\
4 \\
4 \\
25 \\
1 \\
2 \\
20 \\
1 \\
5 \\
2\end{array}$ & $\begin{array}{l}+ \\
0 \\
+ \\
+ \\
+ \\
0 \\
+ \\
+ \\
+ \\
0\end{array}$ & $\begin{array}{r}3 \\
0 \\
3 \\
16 \\
30 \\
0 \\
1 \\
0 \\
52 \\
2\end{array}$ & $\begin{array}{l}+ \\
+ \\
0 \\
+ \\
+ \\
0 \\
0 \\
+ \\
+ \\
+\end{array}$ & $\begin{array}{c}0 \cdot 25 \\
3 \cdot 25 \\
4 \\
3 \\
12 \cdot 50 \\
3 \\
4 \cdot 25 \\
5 \cdot 25 \\
16 \cdot 25 \\
0\end{array}$ & $\begin{array}{l}58 \\
25 \cdot 1 \\
30 \cdot 1 \\
63 \\
35 \cdot 3 \\
65 \cdot 4 \\
51 \cdot 2 \\
35 \cdot 4 \\
36 \\
47\end{array}$ \\
\hline 35 & M 55 & 1 & 0 & 2 & 0 & $5 \cdot 25$ & $71 \cdot 3$ \\
\hline $\begin{array}{l}36 \\
37 \\
38\end{array}$ & $\begin{array}{ll}\text { M } & \mathbf{3 0} \\
\mathbf{M} & \mathbf{4 5} \\
\mathbf{F} & \mathbf{3 0}\end{array}$ & $\begin{array}{c}\text { min } \\
1 \\
9 \\
1 \\
\text { mth }\end{array}$ & $\begin{array}{l}\mathbf{0} \\
\mathbf{0} \\
+\end{array}$ & $\begin{array}{l}2 \\
0 \\
8\end{array}$ & $\begin{array}{l}\mathbf{0} \\
\mathbf{0} \\
+\end{array}$ & $\begin{array}{l}0.25 \\
2.75 \\
7 \cdot 25\end{array}$ & $\begin{array}{l}41 \cdot 2 \\
57 \\
59\end{array}$ \\
\hline $\begin{array}{l}39 \\
40 \\
41 \\
42 \\
43 \\
44 \\
45 \\
46\end{array}$ & $\begin{array}{ll}\mathbf{F} & 21 \\
\mathbf{F} & 25 \\
\mathbf{F} & 38 \\
\mathbf{M} & \mathbf{2 8} \\
\mathbf{F} & \mathbf{5 0} \\
\mathbf{M} & \mathbf{1 8} \\
\mathbf{F} & \mathbf{5 8} \\
\mathbf{M} & \mathbf{2 1}\end{array}$ & $\begin{array}{l}1 \\
1 \\
1 \\
2 \\
3 \\
1 \\
3 \\
1\end{array}$ & $\begin{array}{l}+ \\
0 \\
+ \\
+ \\
+ \\
+ \\
0 \\
0\end{array}$ & $\begin{array}{l}2 \\
0 \\
2 \\
0 \\
0 \\
8 \\
2 \\
4\end{array}$ & $\begin{array}{l}0 \\
0 \\
+ \\
0 \\
0 \\
+ \\
+ \\
+\end{array}$ & $\begin{array}{l}0 \\
14 \cdot 75 \\
13 \cdot 75 \\
4 \cdot 25 \\
8 \cdot 50 \\
1 \cdot 25 \\
0 \\
3 \cdot 75\end{array}$ & $\begin{array}{l}37 \cdot 1 \\
78 \cdot 2 \\
\mathbf{4 3} \cdot 2 \\
57 \cdot 1 \\
78 \cdot 3 \\
56 \cdot 2 \\
\mathbf{4 7 \cdot 3} \\
\mathbf{7 7 \cdot 2}\end{array}$ \\
\hline $\begin{array}{l}47 \\
48\end{array}$ & $\begin{array}{ll}F & 15 \\
F & 35\end{array}$ & $\begin{array}{c}\text { min } \\
\mathbf{1} \\
2\end{array}$ & $\begin{array}{l}+ \\
+\end{array}$ & $\begin{array}{l}7 \\
8\end{array}$ & $\begin{array}{l}+ \\
+\end{array}$ & $12^{7 \cdot 75}$ & $\begin{array}{l}17 \cdot 8 \\
73 \cdot 1\end{array}$ \\
\hline
\end{tabular}

1 Leucocytes: number within normal limits. 
alcian blue. There was considerable variation in intensity of staining with alcian blue not only from case to case but also in adjacent areas of epithelium in the same subject. In general, the most pronounced staining with alcian blue was given by goblet cells on the free surface of the bronchial epithelium and by free mucus adherent to the cell surfaces. The mucus in some goblet cells was stained by both methods. Epithelial metaplasia was noted in four cases; in three it was of squamous and in one of mucous type.

Bronchitics In all cases there was a hyperplasia of goblet cells, some of which had been cast off from the epithelium to leave the basal cells exposed. The mucus, either still contained in the goblet cells or lying free on the epithelial surface, was predominantly alcian blue positive. Metaplasia occurred in five cases; it was of squamous type in one instance and of mucous type in four others.

Asthmatics These subjects also showed pronounced hyperplasia of goblet cells with shedding of many of them, so that in three cases the layer of basal cells was left exposed almost everywhere. The mucus stained predominantly with PAS and in particular free mucus showed a striking loss of staining reaction with alcian blue. One subject showed squamous metaplasia and six showed mucous metaplasia.

\section{BASEMENT MEMBRANE}

Normal subjects The basement membrane was thin and had a fine reticulated structure, and in seven cases it showed local thickening.

Bronchitics In six cases the basement membrane was thick and hyaline.

Asthmatics Thickening and hyalinization occurred in 22 of the 24 subjects.

SUBEPITHELIAL CONNECTIVE TISSUE (lamina propria and submucosa)

Normal subjects The connective tissue was loose and vascular with lacunae due to oedema ( 7 cases) and with many small, thin-walled blood vessels near the basement membrane. A heavy lymphocytic and round-cell infiltration was seen but eosinophils were sparse, being found in only five cases and then accounting for less than $1 \%$ of the total cell count.
Considerable numbers of mast cells were seen, there being 70 per microscopic area of 30 fields as defined above. They formed groups so that there were many in some parts of the sections but none at all in others. The mast cells showed a pronounced variation in form, some being round and others fusiform, oval, or pyriform. In some the metachromatic contents formed large granules, whereas in others they were powder-like. Some mast cells had 'exploded', liberating their granules into the surrounding tissues. There was a preponderance of granular to degranulated mast cells in the ratio of $4: 3$.

Mucous and serous glands were seen in the connective tissue. The former predominated and showed a predilection for staining with PAS. There was considerable variation in intensity of staining.

Bronchitics Capillary blood vessels were greatly increased in number in six cases, with oedema of the surrounding tissues in nine cases. The heavy cellular exudate was predominantly lymphocytic. with sparse numbers of eosinophils and neutrophil polymorphs. Eosinophils were found in 13 cases but accounted for only $0.5 \%$ to $2.75 \%$ of the total cell count.

Seventy-three mast cells per microscopic area of 30 fields were found; those rich in granules predominated in the ratio of about $4: 3$.

Numerous glands, mainly of mucous type, were seen and the mucus they contained stained best with alcian blue.

Asthmatics Here, too, there was an increased number of capillaries ( 7 cases) with proliferation of endothelium and pericapillary histiocytes. Once again the surrounding tissues were oedematous (10 cases).

As in the subjects with chronic bronchitis, the cellular exudate was composed largely of lymphocytes and monocytes, neutrophil polymorphs being seen but rarely. Eosinophils, however, were seen in 21 subjects and accounted for as much as $16.25 \%$ of the total cell count.

There were 50 mast cells per microscopic area of 30 fields, degranulated cells predominating in a ratio of about $33: 15$. This ratio was reflected by 0 the finding of many metachromatic granules $\mathbb{D}$ scattered in the surrounding connective tissue. ? These appearances of degranulation were reminiscent of mast cells treated with hyaluronidase (Salvato, 1958).

There was hyperplasia of mucous glands, but in this group of patients the mucins stained better with PAS than with alcian blue. 


\section{DISCUSSION}

In both the bronchitics and asthmatics there was hyperplasia of mucous glands, both glands and goblet cells being distended with homogeneous mucus with much less evidence of granules of mucinogen than is found in normal bronchial epithelium. In the bronchitics the mucus in goblet cells and lying free on the epithelial surface stained well with alcian blue and might thus be presumed to contain much acid mucopolysaccharide. In the patients with asthma the affinity of the bronchial mucus for PAS suggested a predominance of neutral mucopolysaccharide. In asthmatics there appeared to be hypersecretion of viscous mucus by the goblet cells, while in bronchitics the excess of mucus appeared to arise from the deeper glands. It seems likely that this difference in the site of production of mucus may be responsible for the difference in viscosity of the mucins produced in the two diseases. There seemed to be a greater tendency for the shedding of goblet cells in patients with asthma. In bronchitics, on the other hand, there appeared to be enlargement of the more deeply situated mucous glands.

Thickening and hyalinization of the basement membrane of the bronchial epithelium was characteristic but not pathognomonic of asthma. There was no difference in the incidence and intensity of oedema of the bronchial connective tissues in the three groups of patients studied. The general paucity of evidence of oedema may have been due to the dehydration inherent in fixation. Proliferation of capillary blood vessels occurred in both bronchitics and asthmatics, and in the latter was associated with endothelial proliferation and exudation of histiocytes. While the bronchial capillaries in chronic bronchitis were engorged with blood those in asthma were empty, possibly as a result of haemorrhage due to decreased coagulability of blood due to increased antithrombin activity (Fritschi, 1945).

An exudate of lymphocytes and chronic inflammatory cells was found in normal subjects as well as in bronchitics and asthmatics and was thus not a distinguishing factor between the three groups. Similarly, while neutrophil polymorphs occurred more commonly in chronic bronchitis, their incidence was too irregular to be a distinguishing factor. More important in this respect were the numbers of eosinophils and mast cells present.

Tissue eosinophilia was pronounced in the asthmatics, occurring in no fewer than 21 of the 24 subjects. Eosinophils were found more frequently in the bronchial tissues than in blood or sputum, and in general there was no relation between the numbers found in these three situations. However, in serious cases of asthma (e.g., cases 29 and 33) large numbers of eosinophils were found in the bronchial tissues and in the blood. There was no relation between the presence of eosinophils and definite evidence of allergy. In contrast, tissue eosinophilia in the bronchitics was much less common (13 of 24 patients) and of limited degree (Table I). While the tissue eosinophilia in chronic bronchitis was undoubted compared with normal subjects, it was never associated with increased numbers of eosinophils in the blood or sputum. Furthermore, there was no relation between the severity of chronic bronchitis assessed clinically and the degree of tissue eosinophilia. Hence the results of this study support the conclusion of Leopold (1964) that tissue eosinophilia is highly characteristic of active bronchial asthma. This investigation suggests that when $3 \%$ of the cellular exudate is composed of eosinophils asthma is definitely indicated, although a proportion of cases of asthma indistinguishable clinically from those with higher tissue eosinophil counts will be missed on this criterion ( 7 of 24 cases in this study, Table II).

My study suggests that it is also possible to distinguish bronchial asthma from chronic bronchitis by mast cell counts in the bronchial tissues. In this series bronchitics had an increased number of mast cells while asthmatics had fewer granulated mast cells than normal. Quantitative evaluation of these cells is open to some criticism (Padawer, 1963) since factors such as tissue oedema may separate the cells and artificially decrease their number. Nevertheless statistical analysis suggests that the differences between the three groups in the present investigation are significant $(P=0.01$, Table III). There are also distinguishing qualitative differences, for in

T A B L E II I

ANALYSIS OF VARIANCE

\begin{tabular}{c|c|c|c|c}
\hline $\begin{array}{c}\text { Source of } \\
\text { Variation }\end{array}$ & $\begin{array}{c}\text { Degrees } \\
\text { of } \\
\text { Free- } \\
\text { dom }\end{array}$ & $\begin{array}{c}\text { Non- } \\
\text { degranulated }\end{array}$ & $\begin{array}{c}\text { Degranu- } \\
\text { lated }\end{array}$ & Total \\
\hline $\begin{array}{c}\text { Between } \\
\text { groups }\end{array}$ & $2 / 69$ & $33.49 \mathrm{P}=0.01$ & $2.75 \mathrm{P}=0.1$ & $9 \cdot 20 \mathrm{P}=0.01$ \\
\hline $\begin{array}{c}\text { Between } \\
\text { normals } \\
\text { and } \\
\text { diseased } \\
\text { patients }\end{array}$ & $1 / 69$ & $15.89 \mathrm{P}=0.01$ & $2.83 \mathrm{P}=0.1$ & $2.46 \mathrm{P}=0.1$ \\
\hline $\begin{array}{c}\text { Between } \\
\text { bronchitics } \\
\text { and } \\
\text { asthmatics }\end{array}$ & $1 / 69$ & $55.16 \mathrm{P}=0.01$ & $2.64 \mathrm{P}=0.2$ & $13.79 \mathrm{P}=0.01$ \\
\hline
\end{tabular}


chronic bronchitis the large numbers of mast cells are rich in metachromatic granules, whereas in asthma the cells are in the main degranulated. The paucity of mast cells in asthma is almost certainly due to their being rendered unidentifiable by such degranulation.

It is well known that such qualitative and quantitative changes in mast cells follow anaphylaxis (Mota, 1963) and treatment with histamine liberator 48/80 (Salvato, 1961, 1962, 1963). It is well established that degranulation with a subsequent decrease in the number of recognizable mast cells are morphological effects of the release of histamine (Mota, Beraldo, Ferri, and Junqueira, 1956 ; Keller, 1957 ; Asboe-Hansen, 1957 ; West, 1958; Riley, 1959; Boréus and Chakravarty, 1960 ; Uvnäs, 1961). It seems likely that mast cell degranulation in asthma has the same functional significance.

Many studies have been carried out during recent years to discover the functions of mast cells, but without success. Their presence in large numbers in sites in close contact with the environment, such as the skin, respiratory tract mucosa, tongue, and mucosae of the alimentary canal, suggests that they are in some way concerned in body defence against environmental stresses. They are rich in biologically active substances such as histamine, heparin, hyaluronic acid, proteolytic enzymes, and probably serotonin, and they may act as prime movers in the chain of events which characterizes the inflammatory reaction. The extent of their reactivity to the type of inflammatory stimulus may determine the different forms of tissue reaction to mechanical, thermal, chemical, biological, allergic or non-allergic stresses.

For example, the studies of Archer (1963) have demonstrated that their behaviour may govern tissue eosinophilia. Riley (1959) and West (1959) have shown that eosinophils appear in mastocytomas only when there is a disruption of mast cells. Welsh and Geer (1959) describe phagocytosis by eosinophils of granules of mast cells disrupted by $48 / 80$. Sheldon and Bauer (1960) found eosinophilia in inflammatory lesions of rats when the mast cells discharged their granules, but to a much lesser extent in diabetic rats when the tissue mast cells retained their granules. Hence in bronchial asthma the tissue eosinophilia may be secondary to massive degranulation of mast cells.

These findings are in striking contrast to the state of affairs in chronic bronchitis, where the mast cells retain their granules and there is no appreciable tissue eosinophilia. Mast cell proliferation in bronchitics does not seem to be related to the formation of young fibrous tissue. Amerio, Pipitone, Carrozzo, and Numo (1966) have $\frac{\bar{\sigma}}{\circ}$ observed an increased urinary output of $5-\frac{\bar{c}}{\bar{c}}$ hydroxy-indole acetic acid (a catabolite of $\overrightarrow{\widetilde{\Phi}}$ serotonin) in patients with chronic bronchitis treated with reserpine, tryptophan, or both. This was especially pronounced in subjects with cor $\overrightarrow{0}$ pulmonale. The site of accumulation of serotonin $\overrightarrow{-}$ could be the mast cells.

In conclusion these histological studies lend $\stackrel{\mathscr{\rho}}{\vec{F}}$ support to the view that chronic bronchitis and $\times$ asthma are two quite distinct diseases, both with $\mathrm{N}$ a characteristic pathology. One of the most inter-? esting and unsettled problems in the pathology of $\vec{\infty}$ these two conditions is the role of the mast cells. 0

I wish to thank Dr. A. Colombi, of the Biometrical Centre, Milan University, for his help with the $\overline{3}$ statistical significance of the data.

\section{REFERENCES}

Amerio, A., Pipitone, V., Carrozzo, M., and Numo, R. (1966), $\vec{c}$ Variazioni del metabolismo della 5-idrossitriptamina nelle broncopneumopatie croniche. Minerva med., 57, 55.

Archer, R. K. (1963). The Eosinophil Leucocytes. Blackwell, Oxford. $\square$ Asboe-Hansen, G. (1957). On the structure and functions of the mast cell. In Connective Tissue: A symposium organized by the $\sum$ Council for International Organizations of Medical Sciences, London, 1956, ed. R. E. Tunbridge, M. Keech, J. F. Dela- o fresnaye, and G. C. Wood, p. 12. Blackwell, Oxford.

Boréus, L. O., and Chakravarty, N. (1960). The histamine content of $\frac{\mathrm{Q}}{\mathrm{Q}}$ guinea pig mast cells. Experientia (Basel), 16, 192.

Cardell, B. S. (1963). La patologia dell'asma bronchiale. Recenti Progr. Med., 35, 475.

Fritschi, W. (1945). Dissertation, Zürich.

Keller, R. (1957). Tissue mast cells in anaphylactic shock and anaphylactoid reactions. Int. Arch. Allergy, 11, 328.

Leopold, J. G. (1964). Personal communication.

Mota, I. (1963). Mast cells and anaphylaxis. Ann. N.Y. Acad. Sci., $103,264$.

- Beraldo, W. T., Ferri, A. G., and Junqueira, L. C. U. (1956) Action of $48 / 80$ on the mast cell population and histamine content of the wall of the gastro-intestinal tract of the rat. In Ciba Foundation Symposium on Histamine. p. 47. Churchill, Ciba Foundation Symposium on Histamine. p. 47. Churchill,
London. dawer, J. Acad. Sci., 103, 87.

Riley, J. F. (1959). The Mast Cells. Livingstone, Edinburgh and

Salvato, G. (1958). Studio istomorfologico e istochimico della mucosa $\bigcirc$ bronchiale nell 'asma. Minerva med. (Parte sci.), 49, 2868.

(1959). Mast cells in bronchial connective tissue of man. I Experientia (Basel), 15, 308.

- (1961). Mast cells in bronchial connective tissue of man: their modifications in asthma and after treatment with the histamine $\mathrm{N}$
liberator 48/80. Int. Arch. Allergy, 18, 348.

(1962). Asthma and mast cells of bronchial connective tissue. Experientia (Basel), 18, 330.

(1963). Ineffectiveness of antihistamines to inhibit mast cells $\mathrm{N}$ damage by compound $48 / 80$ in man. Acta allerg. $(K b h), 18,$.529 . $\omega$

Sheldon, W. H., and Bauer, H. (1960). Tissue mast cells and acute inflammation in experimental cutaneous mucormycosis of normal, 48/80-treated, and diabetic rats. J. exp. Med., 112, 1069.

Shelley, W. B., and Juhlin, L. (1962). Functional cytology of the human basophil in allergic and physiologic reactions: technic \& and atlas. Blood, 19, 208.

Uvnäs, B. (1961). Mechanism of release from mast cells. Chemotherapia (Basel), 3, 137.

Welsh, R. A., and Geer, J. C. (1959). Phagocytosis of mast cell granule by the eosinophilic leukocyte in the rat. Amer. J. Path., 35, 103.

West, G. B. (1958). Comparison of the release of histamine and 5-hydroxytryptamine from tissues of the rat, mouse and hamster. Int. Arch. Allergy, 13, 336.

(1959). Tissue mast cells and tissue amines. J. Pharm. Pharmacol., $11,513$. 